\title{
Increased body mass index and adjusted mortality in ICU patients with sepsis or septic shock: a systematic review and meta-analysis
}

Dominique J. Pepper ${ }^{1 *}$, Junfeng Sun ${ }^{1}$, Judith Welsh ${ }^{2}$, Xizhong Cui ${ }^{1}$, Anthony F. Suffredini ${ }^{1}$ and Peter Q. Eichacker ${ }^{1}$

\begin{abstract}
Background: At least $25 \%$ of adults admitted to intensive care units (ICU) in the United States have an overweight, obese or morbidly obese body mass index (BMI). The effect of BMI on adjusted mortality in adults requiring ICU treatment for sepsis is unclear. We performed a systematic review of adjusted all-cause mortality for underweight, overweight, obese and morbidly obese BMIs relative to normal BMI for adults admitted to the ICU with sepsis, severe sepsis, and septic shock.
\end{abstract}

Method: PubMed, the Cochrane Library, and EMBASE electronic databases were searched through November 18, 2015, without language restrictions. We included studies that reported multivariate regression analyses for all-cause mortality using standard BMI categories for adults admitted to the ICU for sepsis, severe sepsis, and septic shock. Articles were selected by consensus among multiple reviewers. Electronic database searches yielded 10,312 articles, of which six were eligible. Data were extracted by one reviewer and then reviewed by three independent reviewers. For the meta-analyses performed, the adjusted odds ratios (aOR) of mortality were combined using a random-effects model. Risk of bias was assessed using the Newcastle-Ottawa quality assessment scale for cohort studies.

Results: Four retrospective ( $n=6609$ patients) and two prospective $(n=556)$ studies met inclusion criteria. Compared to normal BMI, across five studies each, overweight or obese BMls reduced the adjusted odds ratio (95\% Cl) of mortality [aOR] $[0.83(0.75,0.91) p<0.001$ and $0.82(0.67,0.99) p=0.04$, respectively] with low or moderate heterogeneity $\left(I^{2}=15.7 \%, p=0.31\right.$ and $I^{2}=53.0 \%, p=0.07$, respectively). Across three studies each, morbidly obese $\mathrm{BMI}$ and underweight BMI did not alter aOR $\left[0.90(0.59,1.39), p=0.64 ;\left.\right|^{2}=43.3 \%, p=0.17\right.$; and $1.24(0.79,1.95), p=0.35 ;\left.\right|^{2}=15.6 \%$, $p=0.31$ respectively]. Only one study clearly defined how and when height and weight measurements were calculated. Site of underlying infection and illness severity may have favored overweight and obese BMls.

Conclusions: This is the first meta-analysis to show that overweight or obese BMls reduce adjusted mortality in adults admitted to the ICU with sepsis, severe sepsis, or septic shock. More rigorous studies that address these limitations are needed to clarify the impact of BMI on sepsis ICU outcomes.

Trial registration: PROSPERO International prospective register of systematic reviews 10.15124/CRD42014010556. Registered on July 11, 2014.

Keywords: Sepsis, Obesity, Overweight, Body mass index, Mortality, Meta-analysis

\footnotetext{
* Correspondence: dominique.pepper@nih.gov

${ }^{1}$ Critical Care Medicine Department, Clinical Center, National Institutes of

Health, Clinical Center Building 10, Room 2C145, 10 Center Drive, Bethesda,

MD 20892, USA

Full list of author information is available at the end of the article
}

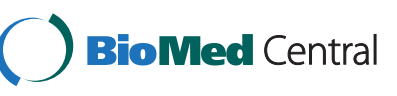

(c) 2016 The Author(s). Open Access This article is distributed under the terms of the Creative Commons Attribution 4.0 International License (http://creativecommons.org/licenses/by/4.0/), which permits unrestricted use, distribution, and reproduction in any medium, provided you give appropriate credit to the original author(s) and the source, provide a link to the Creative Commons license, and indicate if changes were made. The Creative Commons Public Domain Dedication waiver (http://creativecommons.org/publicdomain/zero/1.0/) applies to the data made available in this article, unless otherwise stated. 


\section{Background}

At least $25 \%$ of adults admitted to intensive care units (ICU) in the United States (US) [1-4] have overweight, obese, or morbidly obese body mass indices (BMIs), while bacterial sepsis [5-7] is commonly the cause for these admissions. Although an obese BMI reduces overall life expectancy $[8,9]$, it is unclear whether it also impacts the acute outcome of ICU patients in general, or with sepsis specifically $[3,4,10]$. While identifying such an association has important prognostic and therapeutic implications, this is difficult because an obese BMI is one of several variables potentially influencing ICU outcomes. Studies addressing this question provide conflicting and unclear results [11].

A recent analysis of seven studies [12] of septic patients found an obese BMI increased [13], decreased [14-16], or had no effect [17-19] on survival. However, two of the studies included non-ICU and ICU patients for whom the overall risk of death would have differed $[13,14]$. Furthermore, one study included children and adults [18], and another study did not account for other baseline variables [19].

Based on the adverse effects of an obese BMI on longterm health, we hypothesized that an increased BMI would also worsen short-term outcomes in adult patients with sepsis requiring ICU care. To examine this question, we performed a meta-analysis of studies in adult patients admitted to the ICU (participants) and treated for sepsis, severe sepsis, or septic shock (interventions/exposures). We examined the effect of different BMI categories (comparisons) on mortality (outcome) after adjusting for other influential baseline variables.

\section{Materials and methods}

\section{Literature search and study selection}

We performed a systematic literature review using published guidelines and registered the planned meta-analysis July 11, 2014 [20-22] in PROSPERO (International prospective register of systematic reviews 10.15124/CR D42014010556). Using search terms listed in Additional file 1, three authors (D.J.P., J.W., and A.F.S.) identified relevant studies in the following databases from inception through November 18, 2015 and without language restrictions: MEDLINE, EMBASE, and the Cochrane Central Register of Controlled Trials (CENTRAL). Included studies were searched for additional references. Author consensus resolved uncertainty regarding study inclusion.

Studies meeting the following criteria were analyzed (Additional file 2): employed prospective or retrospective observational study designs (study design); enrolled adult patients ( $\geq 16$ years old) admitted to the ICU (participants) and treated for sepsis, severe sepsis, or septic shock (intervention/exposures); compared mortality (outcome) in patients across two or more BMI categories (comparisons)
[23]; and employed multivariate analysis to adjust the effect of elevated BMI on mortality with other baseline variables. Although the search strategy included types of illnesses associated with sepsis (e.g., pneumonia and influenza), only studies that enrolled patients based on accepted definitions for sepsis, severe sepsis, or septic shock [24-26] were included in the systematic review and meta-analysis [22]. A priori, studies of trauma, primary surgical conditions, or surgical interventions complicated by nosocomial infection, and studies available only as abstracts were excluded [22].

\section{Data extracted and outcomes examined}

Data was extracted from included studies using a standardized tool (Additional file 3). Definitions of sepsis, severe sepsis, and septic shock employed in studies had to be consistent with recognized and accepted definitions [24-26]. Of note, all studies were conducted prior to the new guideline nomenclature for sepsis and septic shock. The definitions and nomenclature used in these prior studies were used in our study. Authors of included studies were contacted when data required clarification.

The primary outcome examined was the effect of BMI on the adjusted odds ratio of mortality, considered in the following hierarchy: ICU, hospital, 28-day, 30-day, or 60 -day mortality. Outcomes are presented based on comparisons between patients with normal BMI (18.5 to $<25 \mathrm{~kg} / \mathrm{m} 2)$ versus those with underweight $(<18.5 \mathrm{~kg} / \mathrm{m} 2)$, overweight ( 25 to $<30 \mathrm{~kg} / \mathrm{m} 2$ ), obese (30 to $<40 \mathrm{~kg} / \mathrm{m} 2$ ), or morbidly obese $(\geq 40 \mathrm{~kg} / \mathrm{m} 2)$ BMIs. Composite outcomes were not examined.

\section{Statistical analysis}

For the meta-analyses performed, the adjusted odds ratios (aOR) of mortality were combined using a random-effects model [27]. If a study reported an adjusted hazard ratio (aHR) instead of an adjusted odds ratio, the aHR was converted to aOR using the observed normal BMI group mortality rate with the assumption of proportional hazard. For example, in the study by Wacharasint et al. [16], the 28-day mortality rate of the normal BMI group was used. When the estimated effect was based on a continuous measure of BMI (i.e., aOR of mortality when BMI increases by $1 \mathrm{~kg} / \mathrm{m} 2$ ), the midpoint of the BMI category was used in the analysis (e.g., BMI of $22 \mathrm{~kg} / \mathrm{m} 2$ used for normal BMI [18.5-25 kg/m2], BMI of $27.5 \mathrm{~kg} / \mathrm{m} 2$ for overweight [25-30 kg/m2] and BMI of $35 \mathrm{~kg} / \mathrm{m} 2$ for obesity [30-40 kg/m2]). Heterogeneity among studies was assessed statistically using the standard chi-square tests and $\mathrm{I}^{2}$ values [28]. Risk of bias of individual studies for outcomes was assessed using the Newcastle-Ottawa quality assessment scale for cohort studies (Additional file 4). Because only three to five studies were present in each BMI subgroup, publication bias could not be assessed. A priori, 
we combined obese BMI data from five studies with overweight BMI data from the one study without obese patients to strengthen our ability to detect an effect of moderately increased BMI on adjusted mortality. All analyses were performed using $\mathrm{R}$ (version 3.1.0) packages meta (version 4.1-0) $[29,30]$. Two-sided $p$ values $\leq 0.05$ were considered significant. This review was prepared according to the PRISMA statement checklist (Additional file 5).

\section{Results}

Our literature search identified 10,312 articles, 656 of which underwent full-text review and six of which met our inclusion criteria (Fig. 1). These six studies examined the effects of BMI on adjusted mortality in adult ICU patients with sepsis, severe sepsis, or septic shock [15-17, 31-33]. These six ( $\mathrm{n}=7165$ patients) studies examined the effect of BMI on mortality (ICU, 28-day, 30-day, and 60-day in hospital mortality in one study each and hospital mortality in two studies) after adjusting for other baseline characteristics (Tables 1 and 2) [15-17, 31-33]. All six studies were included in our meta-analysis.

Of the six studies examining mortality, two were prospective; one a single-center study from Germany [32] and the other a multicenter one from 24 European countries, which included a subgroup of patients with septic shock [31]. The other four studies were all retrospective; a single- center study from Austria [15] and three multicenter studies, one from the US, Canada, and Saudi Arabia [17], one from the US, Canada, and Australia [16] and one from 730 ICUs from 84 countries [33]. In studies assessing mortality, the proportion of patients investigated from the populations of patients identified as having sepsis, severe sepsis, or septic shock varied from 33 to $94 \%$ (Table 3). Three of these studies included patients with BMIs calculated only from weight and height measures [15-17] while two studies included patients with estimated BMIs [31, 32], and another did not report how BMI was determined [32]. Only one study reported that BMI was determined before ICU admission and before fluid therapy potentially altered this determination [16].

Four studies adjusted the effect of BMI on mortality using age $[15,17,32,33]$, five adjusted for gender and comorbid illnesses [15-17, 32, 33], and all six adjusted for severity of acute illness with either Simplified Acute Physiology Score (SAPS) II or Acute Physiology and Chronic Health Evaluation (APACHE) II scores (Table 2). Other variables examined in each study are noted in Table 2. Three studies reported the effect of BMI on the adjusted odds ratio (aOR) of mortality $[15,17,31]$. Three studies reported adjusted hazards ratios, which were converted to aORs of mortality as described in the materials and methods section [16, 32, 33].

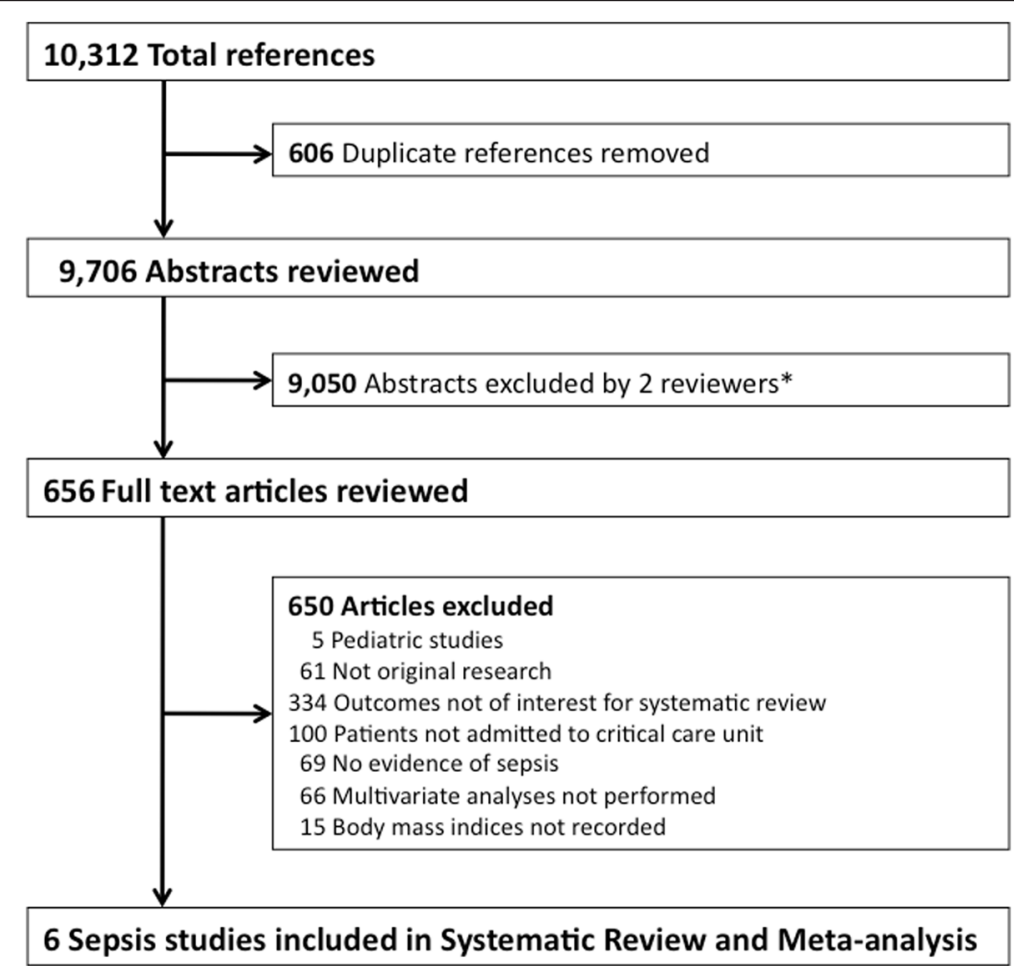

Fig. 1 Study selection flow diagram. *Studies involving trauma, primary surgical conditions, or surgical interventions complicated by nosocomial infections, as well as studies of children, and those occurring outside the critical care unit were excluded 
Table 1 Study characteristics

\begin{tabular}{|c|c|c|c|c|c|c|c|}
\hline Author $(Y)$ & Country & Study design & $\begin{array}{l}\text { Study period } \\
(\mathrm{MM} / \mathrm{YY})\end{array}$ & Diagnostic criteria & $\begin{array}{l}\text { Age, years } \\
\text { Median (IQR or SD) }\end{array}$ & Male (\%) & Outcome \\
\hline \multicolumn{8}{|c|}{ Studies of sepsis, severe sepsis and septic shock ${ }^{a}$} \\
\hline Sakr [31] (2008) & $\begin{array}{l}24 \text { European } \\
\text { countries }^{b}\end{array}$ & $\begin{array}{l}\text { Prospective cohort, } \\
\text { multicenter }\end{array}$ & 05/02-05/02 & Septic shock [25] & NR & NR & Hospital mortality \\
\hline Wurzinger [15] (2010) & Austria & $\begin{array}{l}\text { Retrospective cohort, } \\
\text { single center }\end{array}$ & 01/03-12/08 & Septic shock [25] & $69(14)$ & $162(54)$ & ICU mortality \\
\hline Adamzik [32] (2011) & Germany & $\begin{array}{l}\text { Prospective cohort, } \\
\text { single center }\end{array}$ & $N R$ & Severe sepsis [25] & $57(16)$ & $90(58)$ & 30-day mortality \\
\hline Arabia [17] (2013) & $\begin{array}{l}\text { Canada, USA } \\
\text { Saudi Arabia }\end{array}$ & $\begin{array}{l}\text { Retrospective cohort, } \\
\text { multicenter }\end{array}$ & /96-/08 & Septic shock [25] & NR & $1658(58)$ & Hospital mortality \\
\hline Wacharasint [16] (2013) & $\begin{array}{l}\text { Australia, } \\
\text { Canada, USA }\end{array}$ & $\begin{array}{l}\text { Retrospective cohort, } \\
\text { multicenter }\end{array}$ & 07/01-04/06 & Septic shock [25] & NR & $449(62)$ & 28-day mortality \\
\hline Sakr [33] (2015) & 84 countries $^{c}$ & $\begin{array}{l}\text { Retrospective } \\
\text { worldwide audit }\end{array}$ & $05 / 12-05 / 12$ & Sepsis [26] & NR & NR & $\begin{array}{l}\text { 60-day in-hospital } \\
\text { mortality }\end{array}$ \\
\hline
\end{tabular}

NR not reported

${ }^{\mathrm{a}}$ Definitions of sepsis, severe sepsis and septic shock in these studies included Bone et al. [25] and Vincent et al. [26]

${ }^{\mathrm{b}}$ Austria, Belgium, Czech Republic, Denmark, Finland, France, Germany, Greece, Hungary, Ireland, Israel, Italy, Netherlands, Norway, Poland, Portugal, Romania, Serbia and Montenegro, Slovakia, Slovenia, Spain, Sweden, Switzerland, and United Kingdom

'List of 84 countries detailed in the following link: http://links.Iww.com/CCM/B435

When stratified by BMI category, compared to a normal BMI (18.5 to $\left.25 \mathrm{~kg} / \mathrm{m}^{2}\right)$ overweight $\left(25\right.$ to $\left.<30 \mathrm{~kg} / \mathrm{m}^{2}\right)$ and obese $\left(30\right.$ to $\left.<40 \mathrm{~kg} / \mathrm{m}^{2}\right)$ BMIs across five studies, each were associated with decreases in mortality that were significant [aOR: $0.83(0.75,0.91), p=0.0002]$ and [aOR: 0.82 (0.67, 0.99), $p=0.04$, respectively] (Fig. 2). These effects appeared consistent with low heterogeneity across studies examining overweight BMIs $\left(\mathrm{I}^{2}=15.7 \%, p=0.31\right)$ but were less consistent with moderate heterogeneity across studies of obese BMIs $\left(\mathrm{I}^{2}=53 \%, p=0.07\right)$. To strengthen our ability to detect an effect of moderately increased BMI on adjusted mortality, we combined obese BMI data from five studies with overweight BMI data from the one study without obese patients. Across these six patient groups (five obese and one overweight), the effects of increased $\mathrm{BMI}$ on reducing mortality were significant [aOR: 0.82 $(0.69,0.97), p=0.02]$ and but had moderate heterogeneity $\left(\mathrm{I}^{2}=42 \%, p=0.13\right)$. Over three studies each, morbidly obese $(\geq 40 \mathrm{~kg} / \mathrm{m} 2)$ and underweight $(<18.5 \mathrm{~kg} / \mathrm{m} 2)$ BMIs were not significantly associated with mortality [aOR: 0.90 $(0.59,1.39), p=0.64 ; \mathrm{I}^{2}=43.3 \%, p=0.17$ and aOR: 1.24 $(0.79,1.95), p=0.35 ; \mathrm{I}^{2}=15.6 \%, p=0.31$, respectively].

Risk of bias of each study was assessed using the Newcastle-Ottawa quality assessment scale for cohort studies (Additional file 4). Publication bias was to be assessed by funnel plot and Egger's regression if sufficient data was available [34]. Because only three to five studies were present in each BMI subgroup, publication bias could not be assessed.

\section{Discussion}

Different from our hypothesis, in studies of adults admitted to the ICU with sepsis, severe sepsis, or septic shock and which adjusted for other baseline variables, patients with overweight or obese BMIs, but not with morbidly obese ones, had reductions in mortality at up to 60 days compared to those with normal BMIs. There are several plausible biologic and physiologic reasons for these mortality reductions with the two former categories. First, increased adipose tissue is associated with increased renin-angiotensin system activity [35]. While this increased activity contributes to the hypertension of overweight and obese patients, it could also have protective hemodynamic effects during sepsis and decreased the need for fluid or vasopressor support, therapies which in excess can adversely impact outcome [36]. Second, increased lipoprotein levels and adipose tissue in patients with increased BMI may bind and inactivate lipopolysaccharide or other harmful bacterial products released during sepsis [37, 38]. Third, excess adipose tissue could provide increased beneficial energy stores during the catabolic septic state [39]. Finally, excess adipose tissue may have beneficial immune functions. For example, adipose tissue has been associated with increased production of both tumor necrosis factor (TNF) and soluble TNF receptor [40, 41]. While increased TNF production might augment protective host defense mechanisms during infection, increased soluble TNF receptor levels could reduce the deleterious effects of excessive TNF production during sepsis. Studies have suggested that obesity suppresses injurious inflammatory mediator release during sepsis and sepsis-associated acute lung injury [42].

Although morbidly obese BMIs were not associated with reductions in mortality, they, perhaps surprisingly, were also not associated with mortality increases. However, there were few studies and considerably fewer patients with morbidly obese BMIs investigated, and this may have limited our ability to demonstrate a potential 
Table 2 Studies with multivariate analyses for mortality

\begin{tabular}{|c|c|c|c|c|c|c|c|c|}
\hline \multirow[b]{2}{*}{ Author (Y) (Total patients) } & \multirow[b]{2}{*}{ BMI studied (kg/m2) } & \multirow[b]{2}{*}{ Non-survivor/total } & \multirow[b]{2}{*}{ BMI } & \multirow[b]{2}{*}{ Age } & \multirow[b]{2}{*}{ Gender } & \multicolumn{3}{|l|}{ Baseline study characteristics } \\
\hline & & & & & & Comorbid illnesses & Severity of acute illness & Other \\
\hline \multicolumn{9}{|c|}{ Studies of sepsis, severe sepsis, and septic shock } \\
\hline \multirow[t]{5}{*}{ Sakr [31] (2008) (n=431) } & Underweight $(<18.5)$ & $\mathrm{NR} / 17^{\mathrm{C}}$ & \multirow[t]{5}{*}{ NR } & \multirow[t]{5}{*}{ NR } & \multirow[t]{5}{*}{ NR } & \multirow[t]{5}{*}{ NR } & \multirow[t]{5}{*}{ SAPS $\|$} & \multirow[t]{5}{*}{ NR } \\
\hline & Normal (18.5-24.9) & $N R / 179^{c}$ & & & & & & \\
\hline & Overweight (25-29.9) & $N R / 148^{c}$ & & & & & & \\
\hline & Obese (30-39.9) & $N R / 76^{c}$ & & & & & & \\
\hline & Very obese $(>40)$ & $\mathrm{NR} / 11^{\mathrm{C}}$ & & & & & & \\
\hline \multirow[t]{4}{*}{ Wurzinger [15] (2010) $(n=301)$} & Underweight $(<18.5)$ & $3 / 15$ & \multirow[t]{4}{*}{ Yes $^{d}$} & \multirow[t]{4}{*}{ Yes } & \multirow[t]{4}{*}{ Yes } & \multirow{4}{*}{$\begin{array}{l}\text { COPD, HTN, DM, CRI, HO, } \\
\text { heart disease }\end{array}$} & \multirow[t]{4}{*}{ SAPS $\|^{d}$} & \multirow[t]{4}{*}{ Admission year, origin of sepsis } \\
\hline & Normal (18.5-24.9) & $28 / 125$ & & & & & & \\
\hline & Overweight (25-29.9) & $15 / 95$ & & & & & & \\
\hline & Obese (30-39.9) & $4 / 66$ & & & & & & \\
\hline Adamzik [32] (2011) ( $n=125)$ & Continuous $\mathrm{BMI}^{\mathrm{a}}$ & NR & Yes & Yes & Yes & Hemofiltration/dialysis & SAPS II, SOFA score & $\begin{array}{l}\mathrm{IL}^{\mathrm{d}} \mathrm{d}^{\mathrm{d}} \text {, aquaporin } 5 \text { genotype }{ }^{\mathrm{d}} \text {, } \\
\text { CRP, serum aldosterone, } \\
\text { plasma angiotensin II, procalcitonin }\end{array}$ \\
\hline \multirow[t]{5}{*}{ Arabi [17] (2013) $(n=2882)$} & Underweight $(<18.5)^{\mathrm{b}}$ & $121 / 196$ & \multirow[t]{5}{*}{ Yes } & \multirow[t]{5}{*}{ Yes } & \multirow[t]{5}{*}{ Yes } & \multirow[t]{5}{*}{ ID, HF, COPD, DM, Elective surgery } & \multirow[t]{5}{*}{ APACHE ॥ } & \multirow{5}{*}{$\begin{array}{l}\text { Type and source of bacterial } \\
\text { infection, type of sepsis interventions }\end{array}$} \\
\hline & Normal (18.5-24.9) & $580 / 1020$ & & & & & & \\
\hline & Overweight $(25-29.9)^{b}$ & $444 / 816$ & & & & & & \\
\hline & Obese (30-39.9) & $349 / 680$ & & & & & & \\
\hline & Morbidly obese (>40) & $76 / 170$ & & & & & & \\
\hline Wacharasint [16] (2013) $(n=730)$ & Continuous BMI & NR & $Y_{e s}^{d}$ & NR & Yes & DM & APACHE $\|^{d}$ & Lung infection, fungal infection \\
\hline \multirow[t]{5}{*}{ Sakr [33] (2015) $(n=2696)$} & Underweight $(<18.5)$ & NR & \multirow[t]{5}{*}{ Yes } & \multirow[t]{5}{*}{ Yes } & \multirow[t]{5}{*}{ Yes } & Comorbidities $^{e}$ & SAPS II, SOFA score & Type and source of admission, need \\
\hline & Normal (18.5-24.9) & NR & & & & & & replacement therapy at ICU admission, \\
\hline & Overweight (25-29.9) & NR & & & & & & type of hospital, ICU specialty, \\
\hline & Obese (30-39.9) & NR & & & & & & number of staffed ICU beds, gross \\
\hline & Very obese (>40) & NR & & & & & & national income of country \\
\hline
\end{tabular}

BMI body mass index, NR not reported, SAPS Simplified Acute Physiology Score, COPD chronic obstructive pulmonary disease, HTN arterial hypertension, DM diabetes mellitus, CRI chronic renal insufficiency, HO

hematologic/oncologic disease, SOFA Sepsis-related Organ Failure Assessment score, IL-6 interleukin-6, CRP C-reactive protein, ID immunodeficiency, HF heart failure, cancer, heart disease, APACHE Acute Physiology and Chronic Health Evaluation, ICU intensive care unit

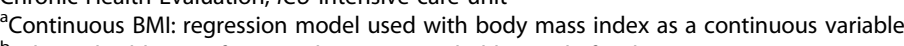

${ }^{\mathrm{b}}$ Adjusted odds ratio for mortality not provided by study for this BMI category

'Numerator not reported

Independently associated with mortality in multivariate analysis

${ }^{e}$ Comorbidities not listed in multivariate analysis 
Table 3 Characteristics of body mass index (BMI) assessment

\begin{tabular}{|c|c|c|c|c|}
\hline \multirow[b]{2}{*}{ Author $(Y)$} & \multirow[b]{2}{*}{ Study populations } & \multicolumn{3}{|l|}{ BMI measurement } \\
\hline & & Method & Timing & $\begin{array}{l}\text { Number with BMI/ } \\
\text { total patients (\%) }\end{array}$ \\
\hline \multicolumn{5}{|c|}{ Studies of severe sepsis, and septic shock } \\
\hline Sakr [31] (2008) & $\begin{array}{l}431 \text { patients with septic shock from } 2878 \\
\text { patients with BMls recorded in a survey of } \\
3147 \text { critically ill patients from } 198 \text { European } \\
\text { countries. The total number of patients with } \\
\text { septic shock out of all } 3147 \text { patients was not } \\
\text { reported }\end{array}$ & $\begin{array}{l}\text { Based either on recorded } \\
\text { weight and height or on } \\
\text { provider's clinical estimate }\end{array}$ & At ICU admission & 2878/3147 (91 \%) \\
\hline Wurzinger [15] (2010) & $\begin{array}{l}301(88 \%) \text { patients with BMls recorded } \\
\text { from } 343 \text { patients with septic shock } \\
\text { admitted to a single ICU in Austria. } \\
\text { A total of } 2700 \text { ICU admissions were } \\
\text { screened to obtain the } 343 \text { patients } \\
\text { with septic shock }\end{array}$ & $\begin{array}{l}\text { Based on recorded weight } \\
\text { and height }\end{array}$ & At ICU admission & $301 / 343(88 \%)$ \\
\hline Adamzik [32] (2011) & $\begin{array}{l}125(81 \%) \text { patients with BMIs recorded } \\
\text { from } 154 \text { patients with severe sepsis } \\
\text { admitted to a single ICU in Germany. } \\
\text { Total number of patients screened } \\
\text { not reported }\end{array}$ & Not reported & Within 24 hrs of diagnosis & 125/154 (81 \%) \\
\hline Arabi [17] (2013) & $\begin{array}{l}2882 \text { ( } 33 \% \text { ) patients with BMls recorded } \\
\text { from } 8670 \text { patients admitted with septic } \\
\text { shock to } 28 \text { ICUs in Canada, Saudi Arabia, } \\
\text { and the USA }\end{array}$ & $\begin{array}{l}\text { Based on recorded weight } \\
\text { and height }\end{array}$ & At ICU admission & 2882/8670 (33 \%) \\
\hline $\begin{array}{l}\text { Wacharasint [16] } \\
\text { (2013) }\end{array}$ & $\begin{array}{l}730 \text { ( } 94 \% \text { ) patients with BMls recorded } \\
\text { from } 778 \text { patients with septic shock } \\
\text { admitted to } 27 \text { ICUs in Australia, Canada } \\
\text { and the USA. A total of } 6229 \text { patients } \\
\text { were screened for the trial and } 802 \text { were } \\
\text { randomized. Number of patients with } \\
\text { septic shock not enrolled is not noted }\end{array}$ & $\begin{array}{l}\text { Based on recorded weight } \\
\text { and height }\end{array}$ & $\begin{array}{l}\text { At study enrollment for } \\
\text { septic shock }\end{array}$ & 730/778 (94 \%) \\
\hline Sakr [33] (2015) & $\begin{array}{l}2696 \text { patients with sepsis from } 8829 \text { patients } \\
\text { with BMIs recorded in a worldwide audit of } \\
10,069 \text { patients admitted to } 730 \text { ICUs in } 84 \\
\text { countries. The total number of patients with } \\
\text { sepsis out of all 10,069 patients was not } \\
\text { reported. Sepsis was defined as infection } \\
\text { with organ failure }\end{array}$ & $\begin{array}{l}\text { Based either on recorded } \\
\text { weight and height or on } \\
\text { provider's clinical estimate }\end{array}$ & $\begin{array}{l}\text { Before onset of critical illness } \\
\text { or at hospital admission }\end{array}$ & $\begin{array}{l}8829 / 10,069 \\
(88 \%)\end{array}$ \\
\hline
\end{tabular}

$B M I$ body mass index, ICU intensive care unit

survival benefit with this category. Also, as discussed further below, there may be a diminishing benefit as BMI levels exceed the overweight and obese categories.

It is possible that methodology in studies may have contributed to an apparent but not real reduction in mortality in septic patients with overweight and obese BMIs. First, mortality may not have been adjusted for baseline variables favoring improved outcomes in overweight and obese patients. While septic patients with increased BMI may have infections (e.g., skin and soft tissue) more responsive to treatment than those with normal BMIs, only two studies adjusted for the site and type of underlying infection [16, 17]. Only one study adjusted for interventions patients received at admission [15]. However, time to antibiotic therapy may have differed across BMI categories and impacted outcomes. Also, administration of non-weight-based therapies such as fluids or vasopressors (e.g., norepinephrine) may have benefited patients with increased BMIs. In two studies analyzed here, when weight was accounted for, septic patients with increased BMI received less overall fluid than normal weight patients and this may have protected organ function [16, 17]. Second, selection bias may have altered the results. Concerns about airway protection and hypoventilation in patients with increased BMI may have prompted intubation with mechanical ventilation and ICU admission in patients with more easily treated infection [43, 44]. Inability to administer adequate care for obese patients on general wards may have also caused ICU admission of obese patients with less severe infection [17]. Third, missing data may have influenced the results. The study with the largest number of septic patients did not provide adjusted mortality rates for those with underweight or overweight BMIs, even after 


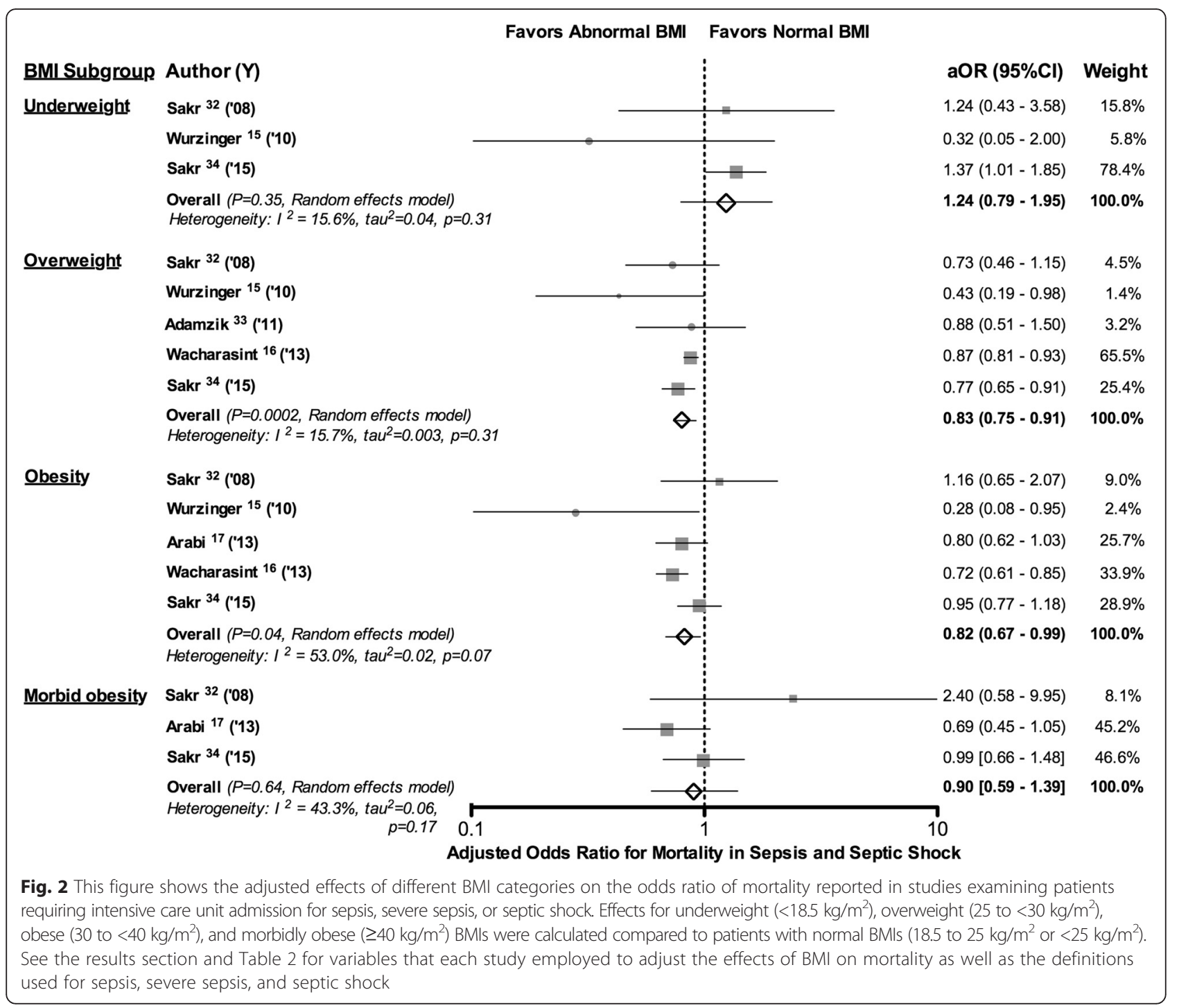

our attempts to obtain this information from investigators. Finally, inaccurate height and weight estimates are common in the ICU setting and may have caused assignment of patients to incorrect BMI categories [45-47]. Weight first measured in the ICU following aggressive emergency room fluid resuscitation may have resulted in patients with normal BMIs at baseline being categorized as overweight or obese at the time of study entry [17]. Notably, only one study appeared to clearly define both how and when height and weight measurements were calculated [16], and no study explicitly reported the reliability of the BMI calculations made.

There are several potential limitations to this study. The most important one has to do with the design and selection of patients included in the studies analyzed. Four of the six studies were retrospective ones, with three of these studies having $87 \%$ of the patients available to examine the influence of BMI on mortality in sepsis. The largest study, a retrospective one, only included $33 \%$ of patients from the population available for analysis due to missing BMI data [17]. This study reported that included patients were significantly different from excluded patients, having fewer comorbid conditions but higher hospital mortality rates (Table 3) [17]. The second-largest study did not report the proportion of patients with sepsis that did not have a recorded BMI [33]. Those with unrecorded BMIs may have had fulminant sepsis and died prior to BMI measurement. This study also examined critical care patients admitted in 84 different countries over a 2 -week period during the year. Clinical practice in intensive care units may have differed across centers and countries, while severity of illness and outcomes may have differed with seasonal variation [33]. The third-largest study was a retrospective analysis of a randomized controlled study of vasopressin therapy that included only $15 \%$ of patients 
screened for enrollment (Table 3) [16]. However these three retrospective studies together contributed $90 \%$ and $89 \%$ respectively to the weight of the analyses suggesting that overweight or obese BMIs reduced adjusted mortality.

Other potential limitations include the following. First, the studies we examined which adjusted for comorbid illnesses that have been associated with increased BMI (e.g., diabetes, coronary artery disease) may have decreased or negated the potential detrimental effects of overweight or obese BMIs [48, 49]. Second, BMI does not differentiate changes in adipose versus muscle tissue. As people age, decreased BMI related to loss of muscle tissue (sarcopenia) [50-52] may be associated with a worsened outcome from sepsis. However, while BMI is not a perfect measure of adiposity [53], routine use of other measures of adiposity such as waist circumference, calipers or computed tomography, are not routinely performed in the ICU. Studies in our review likely utilized BMI as a measure of adiposity, due to its ease of use and measurement. Third, the studies included in this metaanalysis did not describe the types of nutritional support patients were receiving (e.g., low-calorie, high-protein therapy, conventional therapy, or nothing). Differences in nutritional support may have influenced outcome [54]. Finally, all the studies included in this analysis used sepsis definitions that predate the new sepsis-3 guideline nomenclature [55]. Five of the six studies used definitions of severe sepsis and septic shock by Bone et al. [25], and one study used a definition of sepsis by Vincent et al. [26]. As previously noted though, correlations can be drawn between this prior sepsis nomenclature and that of the new sepsis-3 guideline [55].

Despite its potential limitations, this study contributes in several ways to the current literature regarding the influence of increased BMI on outcomes in critically ill patients. With regard to sepsis specifically, a previous systematic review by Trivedi et al. [12] examined outcomes for obese and non-obese BMIs in adults and children admitted with sepsis to both ICU and non-ICU settings but did not incorporate a meta-analysis. Our systematic review has focused only on adult patients requiring ICU admission and has included a meta-analysis. In contrast to the prior review, the present one has also analyzed patients with morbidly obese BMIs and, in employing adjusted outcomes, has highlighted variables future analyses may need to consider (Table 2). Notably, our study and this prior one are in agreement regarding the need for more rigorous investigation into the potential impact of obesity on outcomes in septic patients.

With regard to the potential relationship between increased BMI and outcomes in critically ill patients in general, the present analysis adds to others suggesting that there may be an association between overweight and obese BMIs and unexpected increases in survival [56-58]. This possible relationship has been referred to as the obesity survival paradox since the documented adverse effects of obesity on chronic disease and longterm mortality would reasonably be expected to also worsen and not improve outcomes during acute illness of whatever nature [55]. However, the actual existence and basis for this apparent paradox are debated $[8,59,60]$. More in keeping with expectations, in critically ill populations as in the septic ones analyzed here, patients with underweight or morbidly obese BMIs have demonstrated either no increased survival or worsened survival [61-63]. This has lead to the proposal that the relationship between BMI and outcome during acute disease is U-shaped, with worsened outcomes only apparent at the extremes of increased or decreased BMIs [8, 60, 64]. Whether such a relationship clearly holds for patients with sepsis requires further investigation in well-designed studies that adequately adjust for other confounding conditions and variables.

\section{Conclusions}

Obesity is a rapidly growing problem in the developed world, and determining whether it influences the outcome of critically ill patients with sepsis is important for both therapeutic and prognostic reasons. In this systematic review and meta-analysis of studies of adult patients requiring ICU care, adjusted mortality was reduced with overweight and obese BMIs in patients with sepsis, severe sepsis, and septic shock. However, while the present meta-analysis focused on studies reporting the effects of BMI adjusted for other influential baseline variables, questions regarding study design, patient selection, and BMI measurements make these findings difficult to interpret. Large, prospective studies, employing timely and validated measures of BMI, as well as case or propensity controlled study designs which adjust for multiple potential confounders, are necessary to better define the influence of increased BMI on sepsis ICU outcomes.

\section{Additional files}

Additional file 1: Database search strategies. (DOC $31 \mathrm{~kb}$ )

Additional file 2: Inclusion criteria. (DOC $27 \mathrm{~kb}$ )

Additional file 3: Standardized protocol for data extraction. (DOC $27 \mathrm{~kb}$ ) Additional file 4: Newcastle-Ottawa quality assessment scale for cohort studies. (DOC $36 \mathrm{~kb}$ )

Additional file 5: PRISMA 2009 checklist. (DOC 66 kb)

\section{Abbreviations}

aHR, adjusted hazard ratio; aOR, adjusted odds ratio; APACHE, Acute Physiology and Chronic Health Evaluation; BMI, body mass index; ICU, intensive care unit; SAPS, Simplified Acute Physiology Score; SOFA score, Sepsis-related Organ Failure Assessment score; TNF, tumor necrosis factor 


\section{Funding}

The National Institutes of Health Clinical Center supported this work.

\section{Authors' contributions}

DJP had full access to all of the data in the study and takes responsibility for the integrity of the data and the accuracy of the data analysis, including and especially any adverse effects. DJP, JS, JW, XC, AFS, and PQE contributed substantially to the study design, data analysis, and interpretation. DJP drafted the manuscript, and JS, JW, XC, AFS, and PQE revised it critically for important intellectual content. DJP, JS, JW, XC, AFS, and PQE approve the final version to be published.

\section{Competing interests}

The authors declare that they have no competing interests.

\section{Ethics approval and consent to participate}

All human studies have been approved by the appropriate ethics committee and have therefore been performed in accordance with the ethical standards laid down in the 1964 Declaration of Helsinki and its later amendments.

\section{Author details}

${ }^{1}$ Critical Care Medicine Department, Clinical Center, National Institutes of Health, Clinical Center Building 10, Room 2C145, 10 Center Drive, Bethesda, MD 20892, USA. ${ }^{2}$ National Institutes of Health Library, Clinical Center, National Institutes of Health, Bethesda, MD 20892, USA

\section{Received: 23 March 2016 Accepted: 27 May 2016}

\section{Published online: 15 June 2016}

\section{References}

1. Wang Y, Beydoun MA. The obesity epidemic in the United States-gender, age, socioeconomic, racial/ethnic, and geographic characteristics: a systematic review and meta-regression analysis. Epidemiol Rev. 2007;29:6-28.

2. Yang L, Colditz GA. Prevalence of overweight and obesity in the United States, 2007-2012. JAMA Intern Med. 2015:175(8):1412-3.

3. Akinnusi ME, Pineda LA, El Solh AA. Effect of obesity on intensive care morbidity and mortality: a meta-analysis. Crit Care Med. 2008;36(1):151-8.

4. Oliveros $\mathrm{H}$, Villamor E. Obesity and mortality in critically ill adults: a systematic review and meta-analysis. Obesity (Silver Spring). 2008;16(3):515-21.

5. Vincent $\mathrm{L}$, Sakr Y, Sprung $C L$, et al. Sepsis in European intensive care units: results of the SOAP study. Crit Care Med. 2006;34(2):344-53.

6. Padkin A, Goldfrad C, Brady AR, Young D, Black N, Rowan K. Epidemiology of severe sepsis occurring in the first 24 hrs in intensive care units in England, Wales, and Northern Ireland. Crit Care Med. 2003;31(9):2332-8.

7. Alberti C, Brun-Buisson C, Burchardi $\mathrm{H}$, et al. Epidemiology of sepsis and infection in ICU patients from an international multicentre cohort study. Intensive Care Med. 2002;28(2):108-21.

8. Flegal KM, Kit BK, Orpana H, Graubard BI. Association of all-cause mortality with overweight and obesity using standard body mass index categories: a systematic review and meta-analysis. JAMA. 2013;309(1):71-82.

9. McGee DL. Body mass index and mortality: a meta-analysis based on person-level data from twenty-six observational studies. Ann Epidemiol. 2005;15(2):87-97.

10. Hogue Jr CW, Stearns JD, Colantuoni E, et al. The impact of obesity on outcomes after critical illness: a meta-analysis. Intensive Care Med. 2009;35(7):1152-70

11. Rahman A, Stapleton RD, Heyland DK. Not all critically ill obese patients are the same: the influence of prior comorbidities. ISRN Obes. 2012;743978.

12. Trivedi $V$, Bavishi $C$, Jean R. Impact of obesity on sepsis mortality: a systematic review. J Crit Care. 2015;30(3):518-24.

13. Huttunen R, Laine J, Lumio J, Vuento R, Syrjänen J. Obesity and smoking are factors associated with poor prognosis in patients with bacteraemia. BMC Infect Dis. 2007;7:13.

14. Prescott HC, Chang WW, O'Brien Jr JM, Langa KM, Iwashyna TJ. Obesity and 1-year outcomes in older Americans with severe sepsis. Crit Care Med. 2014:42(8):1766-74.

15. Wurzinger B, Dünser MW, Wohlmuth $C$, et al. The association between body-mass index and patient outcome in septic shock: a retrospective cohort study. Win Klin Wochenschr. 2010;122(1-2):31-6.
16. Wacharasint $P$, Boyd JH, Russell JA, Walley KR. One size does not fit all in severe infection: obesity alters outcome, susceptibility, treatment, and inflammatory response. Crit Care. 2013;17(3):R122.

17. Arabi YM, Dara SI, Tamim HM, et al. Clinical characteristics, sepsis interventions and outcomes in the obese patients with septic shock: an international multicenter cohort study. Crit Care. 2013;17(2):R72.

18. Gaulton TG, Marshall MacNabb C, Mikkesen ME, et al. A retrospective cohort study examining the association between BMl and mortality in severe sepsis. Internal and emergency medicine. Intern Emerg Med. 2015;10(4):471-9.

19. Kuperman EF, Showalter JW, Lehman EB, Leib AE, Kraschnewski JL. The impact of obesity on sepsis mortality: a retrospective review. BMC Infect Dis. 2013;13:377.

20. Stroup DF, Berlin JA, Morton SC, et al. Meta-analysis of observational studies in epidemiology: a proposal for reporting. JAMA. 2000;283(15):2008-12.

21. Booth A, Clarke M, Dooley G, et al. The nuts and bolts of PROSPERO: an international prospective register of systematic reviews. Syst Rev. 2012;1:2.

22. ROSPERO International prospective register of systematic reviews. http:// www.crd.york.ac.uk/PROSPERO/display_record.asp?ID=CRD42014010556. Accessed 12 Apr 2016

23. WHO classification of BMl. 1995. http://apps.who.int/bmi/index. jsp?introPage=intro 3.html. Accessed 12 Apr 2016.

24. Levy MM, Fink MP, Marshall JC, et al. 2001 SCCM/ESICM/ACCP/ATS/SIS International Sepsis Definitions Conference. Crit Care Med. 2003;31(4):1250-6.

25. Bone RC, Sprung CL, Sibbald WJ. Definitions for sepsis and organ failure. Crit Care Med. 1992;20:724-6.

26. Vincent JL, Opal SM, Marshall JC, Tracey KJ. Sepsis definitions: time for change. Lancet. 2013;381(9868):774-5.

27. DerSimonian R, Laird N. Meta-analysis in clinical trials. Controlled Clinical Trials. 1986;7:177-88.

28. Higgins JP, Thompson SG. Quantifying heterogeneity in a meta-analysis. Stat Med. 2002;21(11):1539-58.

29. Core Team R. R Foundation for Statistical Computing. Vienna: Austria. URL; 2014. R: A language and environment for statistical computing, http://www.R-project.org/. Accessed 5 Aug 2015.

30. Schwarzer G. meta: General Package for Meta-Analysis. R package version. 2015:4:1. http://CRAN.R-project.org/package=meta. Accessed 5 Aug 2015.

31. Sakr Y, Madl C, Filipescu D, et al. Obesity is associated with increased morbidity but not mortality in critically ill patients. Intensive Care Med. 2008; 34(11):1999-2009.

32. Adamzik M, Frey UH, Möhlenkamp S, et al. Aquaporin 5 gene promoter1364A/C polymorphism associated with 30-day survival in severe sepsis. Anesthesiology. 2011;114(4):912-7.

33. Sakr Y, Alhussami I, Nanchal R, et al. Being overweight is associated with greater survival in ICU patients: results from the intensive care over nations audit Crit Care Med. 2015:43(12):2623-32.

34. Egger M, Davey Smith G, Schneider M, Minder C. Bias in meta-analysis detected by a simple, graphical test. Brit Med J. 1997:315(7109):629-34.

35. Kershaw EE, Flier JS. Adipose tissue as an endocrine organ. J Clin Endocrinol Metab. 2004:89(6):2548-56.

36. Yealy DM, Kellum JA, Huang DT, et al. A randomized trial of protocol-based care for early septic shock. N Engl J Med. 2014;370(18):1683-93.

37. Ulevitch RJ, Johnston AR, Weinstein DB. New function for high density lipoproteins. Their participation in intravascular reactions of bacterial lipopolysaccharides. J Clin Invest. 1979;64(5):1516-24.

38. Wu A, Hinds CJ, Thiemermann C. High-density lipoproteins in sepsis and septic shock: metabolism, actions, and therapeutic applications. Shock. 2004:21(3):210-21.

39. Thompson PA, Kitchens RL. Native high-density lipoprotein augments monocyte responses to lipopolysaccharide (LPS) by suppressing the inhibitory activity of LPS-binding protein. Immunol. 2006;177(7):4880-7.

40. Winkler $G$, Kiss $S$, Keszthelyi $L$, et al. Expression of tumor necrosis factor (TNF)-alpha protein in the subcutaneous and visceral adipose tissue in correlation with adipocyte cell volume, serum TNF-alpha, soluble serum TNF-receptor-2 concentrations and C-peptide level. Eur J Endocrinol. 2003;149(2):129-35

41. Dinarello CA. Proinflammatory cytokines. Chest. 2000;118(2):503-8.

42. Stapleton RD, Suratt BT. Obesity and nutrition in acute respiratory distress syndrome. Clin Chest Med. 2014;35(4):655-71.

43. De Jong A, Molinari N, Pouzeratte $Y$, et al. Difficult intubation in obese patients: incidence, risk factors, and complications in the operating theatre and in intensive care units. Br J Anaesth. 2015;114(2):297-306. 
44. De Jong A, Molinari N, Terzi N, et al. Early identification of patients at risk for difficult intubation in the intensive care unit: development and validation of the MACOCHA score in a multicenter cohort study. Am J Respir Crit Care Med. 2013;187(8):832-9.

45. Bloomfield R, Steel E, MacLennan G, Noble DW. Accuracy of weight and height estimation in an intensive care unit: implications for clinical practice and research. Crit Care Med. 2006;34(8):2153-7.

46. Maskin LP, Attie S, Setten M, et al. Accuracy of weight and height estimation in an intensive care unit. Anaesth Intensive Care. 2010;38(5):930-4.

47. Leary TS, Milner QJ, Niblett DJ. The accuracy of the estimation of body weight and height in the intensive care unit. Eur J Anaesthesiol. 2000;17(11): 698-703.

48. Ozcan U, Cao Q, Yilmaz E, et al. Endoplasmic reticulum stress links obesity, insulin action, and type 2 diabetes. Science. 2004;306(5695):457-61.

49. Rocha VZ, Libby P. Obesity, inflammation, and atherosclerosis. Nat Rev Cardiol. 2009;6(6):399-409.

50. Ormsbee MJ, Prado CM, Ilich JZ, et al. Osteosarcopenic obesity: the role of bone, muscle, and fat on health. J Cachexia Sarcopenia Muscle. 2014;5(3): 183-92.

51. Gariballa S, Alessa A. Sarcopenia: prevalence and prognostic significance in hospitalized patients. Clin Nutr. 2013;32(5):772-6.

52. Lutz CT, Quinn LS. Sarcopenia, obesity, and natural killer cell immune senescence in aging: altered cytokine levels as a common mechanism. Aging (Albany NY). 2012;4(8):535-46.

53. Romero-Corral A, Somers VK, Sierra-Johnson J, et al. Accuracy of body mass index in diagnosing obesity in the adult general population. Int J Obes (Lond). 2008;32(6):959-66.

54. Robinson MK, Mogensen KM, Casey JD, et al. The relationship among obesity, nutritional status, and mortality in the critically ill. Crit Care Med. 2015;43(1):87-100

55. Singer M, Deutschman CS, Seymour CW, et al. The Third International Consensus Definitions for Sepsis and Septic Shock (Sepsis-3). JAMA. 2016; 315(8):801-10.

56. Fleischmann E, Teal N, Dudley J, et al. Influence of excess weight on mortality and hospital stay in 1346 hemodialysis patients. Kidney Int. 1999; 55:1560-7

57. Niedziela J, Hudzik B, Niedziela N, et al. The obesity paradox in acute coronary syndrome: a meta-analysis. Eur J Epidemiol. 2014;29(11):801-12.

58. Shah R, Gayat E, Januzzi Jr JL, et al. Body mass index and mortality in acutely decompensated heart failure across the world: a global obesity paradox. J Am Coll Cardiol. 2014;63(8):778-85.

59. Dickerson RN. The obesity paradox in the ICU: real or not? Crit Care. 2013; 17(3):154.

60. Hughes V. The big fat truth. Nature. 2013:497(7450):428-30.

61. Hutagalung R, Marques J, Kobylka K, et al. The obesity paradox in surgical intensive care unit patients. Intensive Care Med. 2011;37(11):1793-9.

62. Pickkers $P$, de Keizer $N$, Dusseljee J, et al. Body mass index is associated with hospital mortality in critically ill patients: an observational cohort study. Crit Care Med. 2013;41(8):1878-83.

63. Kitahara CM, Flint AJ, Berrington de Gonzalez A, et al. Association between class III obesity (BMI of 40-59 kg/m2) and mortality: a pooled analysis of 20 prospective studies. PLoS Med. 2014;11(7):e1001673.

64. Sasabuchi $Y$, Yasunaga $H$, Matsui $H$, et al. The dose-response relationship between body mass index and mortality in subjects admitted to the ICU with and without mechanical ventilation. Respir Care. 2015:60(7):983-91.

\section{Submit your next manuscript to BioMed Central and we will help you at every step:}

- We accept pre-submission inquiries

- Our selector tool helps you to find the most relevant journal

- We provide round the clock customer support

- Convenient online submission

- Thorough peer review

- Inclusion in PubMed and all major indexing services

- Maximum visibility for your research

Submit your manuscript at www.biomedcentral.com/submit
C Biomed Central 